\title{
Two brothers with the Marden-Walker syndrome: case report and review
}

\author{
FRANCES M HOWARD AND PIERS ROWLANDSON \\ From the Institute of Child Health, 30 Guilford Street, London WC1, and The Hospital for Sick \\ Children, Great Ormond Street, London WCI
}

SUMMARY Two brothers with blepharophimosis, congenital joint contractures, and mental retarda $\overrightarrow{\bar{\sigma}}_{0}$ tion characteristic of the Marden-Walker syndrome are described. This sib pair strengthens the case for autosomal recessive inheritance of the syndrome.

In 1966, Marden and Walker ${ }^{1}$ writing from Minneapolis described a female infant with blepharophimosis and joint contractures. She died at 3 months of age. There have been subsequent reports but, apart from a pair of first cousins, only of single cases. Hitherto there have been no reports of affected sibs.

We describe here the clinical features of two brothers with the Marden-Walker syndrome. The parents are healthy and unrelated, but both are educationally subnormal (ESN). The mother has had two normal children by different men; we describe the only two children from her present marriage (fig 1).

\section{Case reports}

\section{CASE 1}

This boy (III.5) was born at term on 25.9.78, after an uneventful pregnancy, by lower segment caesarian section for fetal distress. Birthweight was $2.9 \mathrm{~kg}$.

The odd facies was noted at birth (fig 2) and also a left inguinal hernia. At 13 months old the following observations were made: height $74.8 \mathrm{~cm}$ (10th centile); weight $8 \cdot 275 \mathrm{~kg}$ (below the third centile); head circumference $45 \cdot 7 \mathrm{~cm}$ (below the 50 th centile) $\mathrm{He}$ had a tall forehead, immobile facies, depressed nasal bridge, upturned nose, blepharophimosiఖ with widely spaced eyes (inner canthal distance $3.2 \mathrm{~cm} ;>97$ th centile), and epicanthic folds $0_{0}$ micrognathia, a high arched palate, low set simple ears, and a minor degree of pectus excavatum. Ther民 was a left inguinal herniotomy scar. The palmas creases and dermatoglyphs were normal. There were no heart murmurs and the genitalia were normap There were fixed contractures at elbows and knees 8 right elbow, $35^{\circ}$; left elbow, $25^{\circ}$; right knee, $15^{\circ}$ left knee, $10^{\circ}$. There was also some tightness aroun the shoulder joints and also tightness of hip flexors.

Developmentally he was performing at the month old level at 13 months chronological age.

Routine investigations were normal. Radiology electrocardiogram, EMI scan, and ultrasound scą of the kidneys showed no abnormality. Electro myography showed no spontaneous activity and ni myotonic discharges. A normal record was obtaine from tibialis anterior, but there was an increase proportion of spiky polyphasic potentials of normat amplitude from vastus medialis and deltoid. Chromos some analysis showed a normal male karyotype wit

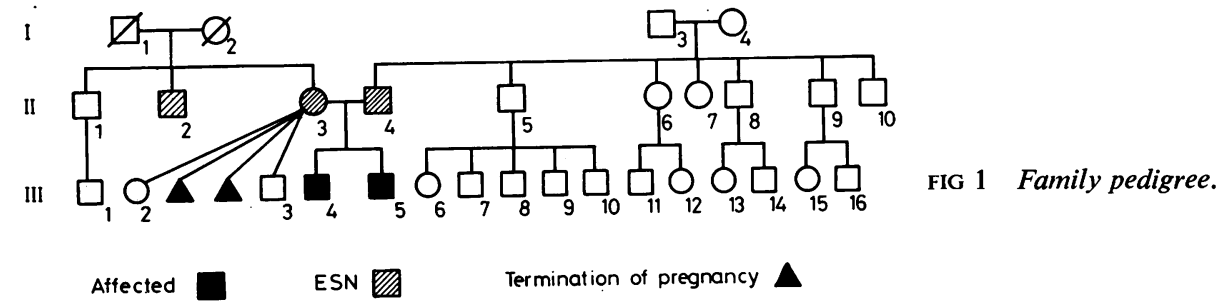



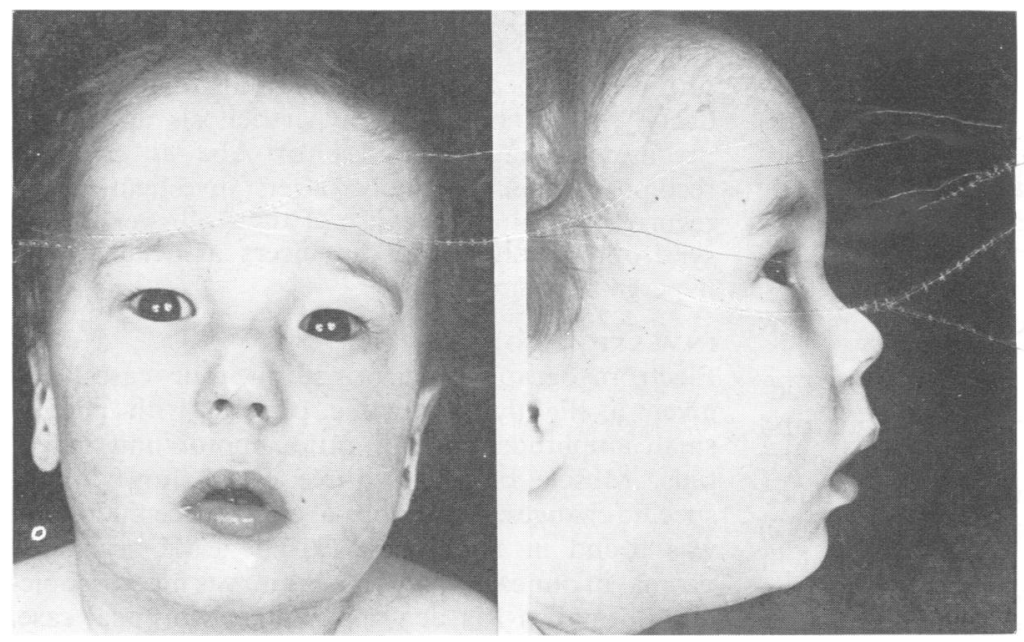

large satellites on chromosome 22. This was also present in the unaffected mother and so was presumably a familial polymorphism.

\section{CASE 2}

This boy (III.4) was born at 34 weeks' gestation on 18.1.73. Birthweight was $1 \cdot 8 \mathrm{~kg}$. When examined at 6 years 10 months old his height was $113.7 \mathrm{~cm}$ (10th centile), weight $19.50 \mathrm{~kg}$ (10th centile), and head circumference $56.0 \mathrm{~cm}$ ( $>97$ th centile).

He has strikingly similar facies to his brother (fig 3). He had bilateral inguinal herniotomy scars. The genitalia were normal. The palmar creases and dermatoglyphs were normal.

He ran and jumped with a stooped posture and had tightness around the shoulder joints and hip flexors; elbows: right, $15^{\circ}$, left $15^{\circ}$; extension supination: right, $25^{\circ}$, left, nil; pronation: right, $25^{\circ}$, left, $10^{\circ}$; knees: (both) extension to neutral.

Routine investigations and electrocardiogram were normal. Skeletal survey showed abnormalities at the elbows: "no dislocation, but there is an abnormality of development of the proximal radial metaphysis with abnormal tilt of the radial heads".

Chromosome analysis showed a normal male karyotype with large satellites on chromosome 22 , similar to those previously found in his brother and mother.

Formal developmental testing at 6 years showed he was functioning at the 4-year-old level [ESN(M)]. However, in language he was only functioning at the 24 month level.
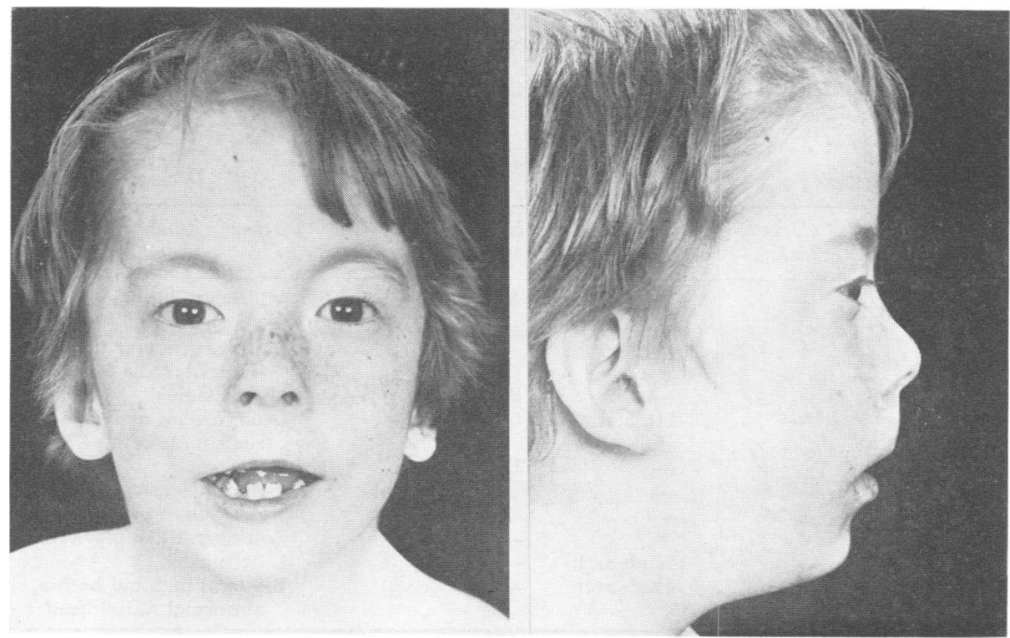

FIG 3 III.4, full face and profile at 6 years 


\section{Discussion}

The Marden-Walker syndrome ${ }^{1}$ is characterised by blepharophimosis (short narrow palpebral fissures) and congenital contractures. These affect the knees, hips, elbows, and ankles and remain stable or slightly improve with time. There is no myotonia, thus differentiating the condition from the SchwartzJampel syndrome. ${ }^{2}$ The blepharophimosis is associated with an immobile facies, micrognathia, and low set ears.

Nine cases (two females and seven males, including our family) have been described in detail, and three others, those of Ealing, ${ }^{3}$ Gethis, ${ }^{4}$ and Passarge, ${ }^{5}$ have been briefly reported. Two of the children died in infancy, and the oldest surviving case (our case 2) is now nearly 7 years old. The mean birthweight was $2.54 \mathrm{~kg}$ (range 2.08 to $2.86 \mathrm{~kg}$ ) and the children have tended to fail to thrive, with weight and height $-2 \mathrm{SD}$ below the mean, although head circumference remains about the mean. All nine cases have been mentally retarded with delayed milestones and marked delay in language development (no speech had been acquired by 5 or nearly 7 years, although hearing was normal, in the two longest survivors). Younessian and Ammann ${ }^{6}$ in 1964 described a further case, but here the diagnosis is, we think, uncertain.

Cleft palate has been observed in two cases (table) and a high arched palate in four others. In Marden and Walker's original case an anomalous connection between the superior and inferior vena cava was found at necropsy. Cardiac lesions in other cases include dextrocardia, ejection systolic murmur, and in the case of Fitch et al, ${ }^{7}$ the heart was clinically normal but with a RBBB (right bundle branch block) on the electrocardiogram.

Genitourinary abnormalities have occurred in five of the nine patients. These were microcystic disease of the right kidney, ${ }^{1}$ hypospadias, ${ }^{8}$ undescended testis, ${ }^{9}$ and inguinal hernia (our family). Two of the $\stackrel{\mathbb{P}}{?}$ children (table, ${ }^{10}$ and our case 2) have anomalies $\overrightarrow{\vec{*}}$ of the radial head; one of these $\mathrm{e}^{10}$ also had campto-? dactyly. One child ${ }^{7}$ had hypertrichosis and a left? preauricular tag. The case of Abe et al ${ }^{11}$ was $\frac{\overline{\bar{c}}}{\bar{s}}$ recognised coincidentally after investigation of $\widetilde{\vec{\sigma}}$ recurrent vomiting because of the Znllinger-Ellison $\propto$ syndrome (multiple gastric ulcers associated with hypergastrinaemia).

\section{INVESTIGATIONS}

Electromyography, performed in four cases, has $\vec{\omega}^{\circ}$ given a slightly myopathic picture, with patchy, $\overline{3}$ small amplitude, short duration motor unit poten tials. Muscle biopsy in three cases showed non- $\vec{\infty}$ specific changes. An abnormal electroencephalogramwas found in two cases. ${ }^{110}$ The EMI scan was normal in our case 1 , and the brain was macroscopic-음 ally normal in Marden and Walker's original case. An AEG in the case of Fitch et $^{\mathrm{al}}{ }^{7}$ showed reduced 7 size of the cerebellum and brain stem. Microcystic음 disease of the kidneys was found at necropsy in that case: IVP on four subsequent cases has been normal. Chromosomes have been reportedly normal in seven $\vec{\bullet}$ cases, while our cases both had large satellites on $\stackrel{\circ}{-}$ chromosome 22, which were also present in theirmother. Dermatoglyphs have been unhelpful.

\section{INHER ITANCE}

Our cases are the only sib pair so far reported. Five cases, three boys and two girls, have been sporadic. $\mathbb{\perp}$ The evidence for autosomal recessive inheritance $\Rightarrow$ previously rested on the male first cousins (related $\frac{0}{3}$ both on the maternal and paternal side) described by? Temtamy et $a l^{9}$ who were both the offspring of at consanguineous marriage. The family described here strengthens the case for autosomal recessive inheritance of the Marden-Walker syndrome.

We thank Professor Otto Wolff and Professor $\mathrm{C} \mathrm{O}$ Carter for permission to report these cases.

TABLE Marden-Walker syndrome: diagnostic features

\begin{tabular}{|c|c|c|c|c|c|c|c|}
\hline Authors & Sex & $\begin{array}{l}\text { Mental } \\
\text { retardation }\end{array}$ & $\begin{array}{l}\text { Blepharo- } \\
\text { phimosis }\end{array}$ & $\begin{array}{l}\text { Contrac- } \\
\text { tures }\end{array}$ & $\begin{array}{l}\text { Cleft } \\
\text { palate }\end{array}$ & Heart & Other \\
\hline Marden and Walker1 & $\mathbf{F}$ & + & + & + & + & $\begin{array}{l}\text { Abnormal sup VC/ } \\
\text { inf } \mathrm{VC} \text { junction }\end{array}$ & Microcystic kidneys; died \\
\hline Fitch et $a l^{7}$ & $\mathbf{M}$ & + & + & + & High arch & - & $\begin{array}{c}\text { Left preauricular tag, } \\
\text { hypertrichosis }\end{array}$ \\
\hline Simpson and Degnan 8 & $\mathbf{M}$ & + & + & + & - & RBBB & Hypospadias \\
\hline \multirow[t]{2}{*}{ Temtamy et al9 } & $\mathbf{M}$ & + & + & + & High arch & & $\begin{array}{l}\text { Died, cousin marriage, } \\
\text { right undescended testis }\end{array}$ \\
\hline & $\mathbf{M}$ & + & + & + & 一 & Dextrocardia & \\
\hline King and Magenis ${ }^{10}$ & $\mathbf{M}$ & + & + & + & 一 & $\begin{array}{l}\text { Ejection systolic } \\
\text { murmur }\end{array}$ & $\begin{array}{l}\text { Camptodactyly, } \\
\text { radioulnar synostosis }\end{array}$ \\
\hline Abe et al 11 & $\mathbf{F}$ & + & + & + & + & 一 & Zollinger-Ellison syndrom \\
\hline This report & $\mathbf{M}$ & + & + & + & High arch & 一 & L hernia \\
\hline & $\mathbf{M}$ & + & + & + & High arch & 一 & $\begin{array}{l}\text { Bilateral inguinal hernia, } \\
\text { abnormal radial head }\end{array}$ \\
\hline
\end{tabular}




\section{References}

1 Marden PM, Walker WA. A new generalised connective tissue syndrome. Am J Dis Child 1966;112:225-8.

2 Schwartz O, Jampel RS. Congenital blepharophimosis associated with a unique generalised myopathy. Arch Ophthalmol 1962;68:52-7.

3 Ealing MI. Amyoplasia congenita causing malpresentation of the fetus. J Obst Gynaecol British Empire 1944;15: 144-6.

4 Gellis SS. Year book of pediatrics. Chicago: Year Book Publishers, 1963:193.

5 Passarge E. Marden-Walker syndrome. Birth Defects: $1975 ; 11: 470-1$

6 Younessian S, Ammann F. Deux cas de malformations crânio-faciales. Opthalmologica 1964;147:108-17.

7 Fitch N, Karpati G, Pinsky L. Congenital blepharophimosis, joint contractures and muscular hypotonia. Neurology $1971 ; 21: 1214-20$.
8 Simpson JL, Degnan M. A child with facial and skeletal dysmorphia reminiscent of Schwartz syndrome. Birth Defects $1975 ; 11: 456-8$.

9 Temtamy SA, Shoukry AS, Raafat M, Miharer S. Probable Marden-Walker syndrome: evidence for autosomal recessive inheritance. Birth Defects 1975;11, No 2: 104-8.

10 King CR, Magenis E. The Marden-Walker syndrome. J Med Genet 1978;15:366-9.

11 Abe K, Niikawa N, Sasaki H. Zollinger-Ellison syndrome with Marden-Walker syndrome. Am J Dis Child 1979; 133:735-8.

Requests for reprints to Dr Frances M Howard, MRC Clinical Genetics Unit, Institute of Child Health, 30 Guilford Street, London WC1N 1EH. 